\title{
Парадуоденальний (groove) панкреатит. Термінологія, етіопатогенез, патоморфологія
}

\begin{abstract}
Парадуоденальний, або groove панкреатит, рідкісний тип фокального хронічного запалення підшлункової залози, що переважно вражає “борозну” - анатомічний простір між дорсокраніальною частиною головки підшлункової залози, дванадцятипалою кишкою та загальною жовчною протокою. В літературі зустрічається під такими синонімами: дуоденальна дистрофія гетеротопічної підшлункової залози, панкреатична гамартома дванадцятипалої кишки, міоаденоматоз. Спірним залишається питання патогенезу парадуоденального панкреатиту. Основними етіопатогенетичними факторами захворювання є анатомічні особливості протокової системи підшлункової залози та підвищення в'язкості панкреатичного соку, які призводять до хронічного персистуючого запалення в ділянці “борозни” з наступним втягненням в патологічний процес головки підшлункової залози, двадцятипалої кишки та термінального відділу холедоха. Тяжкість диференціації groovе панкреатиту з пухлинами періампулярної ділянки створює певні діагностичні труднощі для клініцистів та патоморфологів, що вимагає проведення операційного лікування для верифікації остаточного діагнозу. Дане повідомлення описує основні етіологічні, патофізіологічні та морфологічні зміни, які виникають при парадуоденальному панкреатиті.
\end{abstract}

Ключові слова: парадуоденальний панкреатит; хронічне запалення; підшлункова залоза.

Згідно з даними ВООЗ, щорічно кількість хворих на хронічний панкреатит невпинно зростає. Зокрема, розповсюдженість хронічного панкреатиту у світі складає від 14,5 до 40 випадків на 100 тис. населення. В Україні епідеміологічні показники захворюваності на хронічний панкреатит в 3-4 рази гірші, ніж в Європі, причому захворюваність і розповсюдженість продовжують зростати. За частотою виникнення, тяжкістю клінічного перебігу, труднощами діагностики та лікування хронічний панкреатит займає одне з провідних місць серед патології органів травної системи [2, 3]. Нерідко пацієнти звертаються на пізніх стадіях, з ускладненими формами панкреатиту, тому лише операційне лікування дозволяє зменшити клінічні прояви, запобігти прогресуванню захворювання та покращити якість життя пацієнтів [1, 3].

Парадуоденальний панкреатит $є$ рідкісним типом фокального хронічного запалення підшлункової залози, що переважно вражає “борозну” - анатомічний простір між дорсокраніальною частиною головки підшлункової залози, дванадцятипалою кишкою та загальною жовчною протокою. Характерною особливістю даного захворювання $є$ втягнення в запальний процес стінки низхідного відділу дванадцятипалої кишки, із звуженням ії̈ просвіту, компресією магістральних судин, тубулярним стенозом холедоха, що утруднює диференціацію із злоякісними новоутвореннями періампулярної зони та вимагає розробки і впровадження чітких діагностичних та лікувальних алгоритмів. У літературі зустрічається під такими синонімами: дуоденальна дистрофія $[4,19]$, панкреатична гамартома дванадцятипалої кишки [5, 19], міоаденоматоз [6, 19], groove - панкреатит [7, 19] та інші.

Вперше парадуоденальний панкреатит був описаний Potet i Duclert у 1970 р. [4, 8], як кістозна дистрофія стінки дванадцятипалої кишки. Згодом, в 1973 р. Becker звернув увагу на існування локалізованого хронічного панкреатиту з використанням терміну Rinnenpankreatitis [7], та лише в 1982 p. Stolte ввів в англомовну літературу термін "groovepancreatitis" і описав його як сегментарну форму панкреатиту, що характеризується вогнищевими фіброзними змінами в ділянці “борозни”, гіперплазією залоз Бруннера і тубулярним стенозом холедоха [9]. Дані зміни схематично представлено на рисунку 1.

Поширеність парадуоденального панкреатиту складно оцінити. При ретроспективному аналізі трьох клінічних досліджень у хворих, яким було проведено панкреатодуоденальну резекцію з приводу хронічного панкреатиту або ж при підозрі на злоякісні захворювання періампулярної ділянки, при патологогістологічному дослідженні вдалось підтвердити діагноз groove - панкреатиту, відповідно, у 2,7 \%, 19,5 \%, і 24,4 \% пацієнтів [4, 6, 7]. Більшість 3 цих пацієнтів - чоловіки молодого та середнього віку, які в анамнезі вказували на зловжиння алкоголем та куріння [11, 12, 14].

Етіологія та патогенез парадуоденального панкреатиту достеменно не вивчені, проте виділено ряд факторів, які сприяють виникненню та прогресуванню захворювання:

- такі анатомічні особливості, як відсутність або функціональна обструкція малого сосочка 


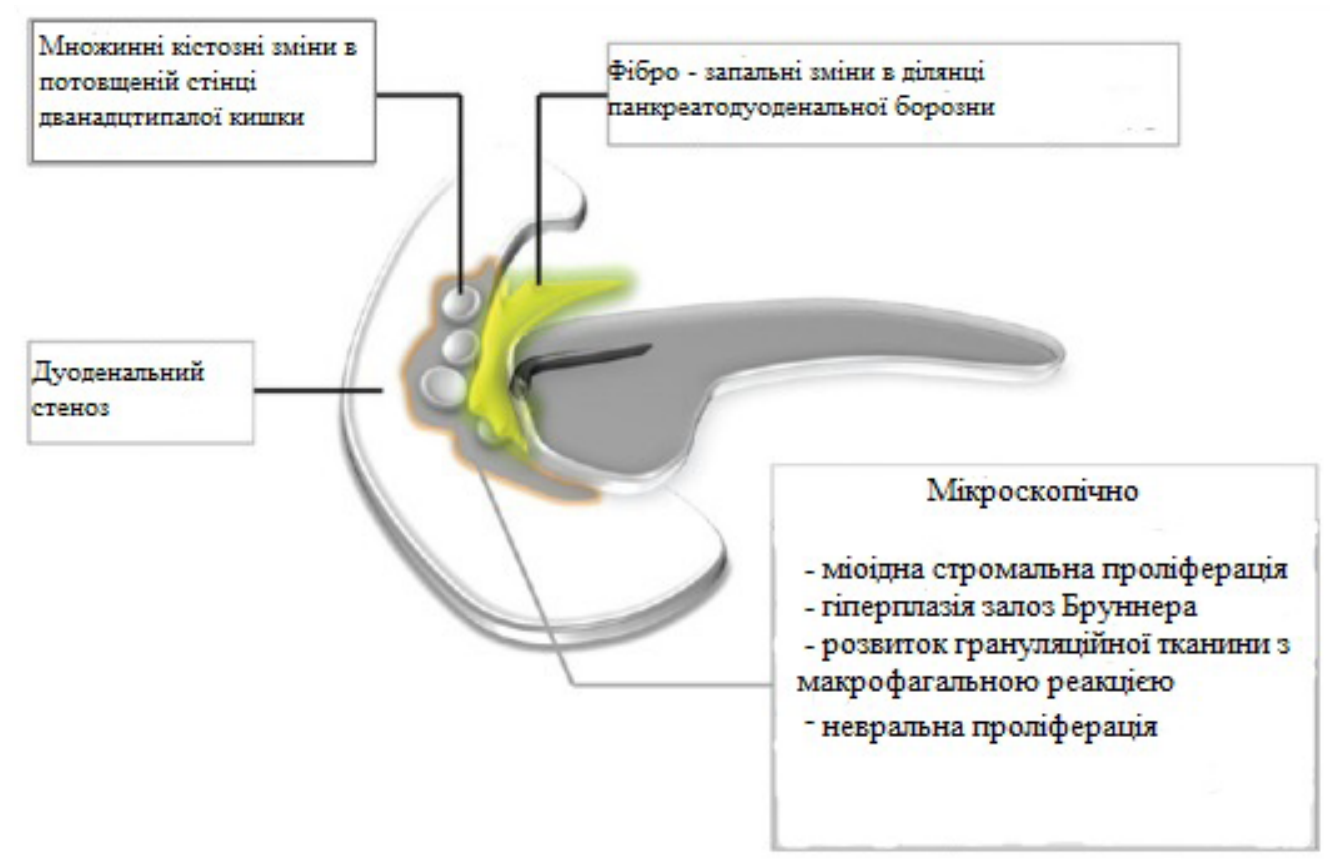

Рис. 1. Макро- та мікроскопічні зміни панкреатодуоденальної ділянки при groove - панкреатиті.

внаслідок потовщення або рубцювання стінки дванадцятипалої кишки; неопластичні процеси в періампулярній ділянці, які утруднюють відтік панкреатичного соку;

- панкреатична гетеротопія в дуоденальній стінці як результат неповної інволюції дорзального зачатку підшлункової залози, з вторинним, локалізованим фіброзним запаленням, кістозною дистрофією, протоковою ектазією;

- pancreasdivisum (наявність фетального типу дренування підшлункової залози - роздільне дренування протокових систем вентрального та дорзального зачатків);

- зловживання алкоголем та куріння, що спричиняє підвищення в’язкості панкреатичного секрету та підвищує інтрадуктальний тиск в додатковій протоці підшлункової залози з наступним її пошкодженням та виділенням панкреатичного соку в “борозну”.

- гіперплазія Бруннерових залоз, яка характерна для парадуоденального панкреатиту, ще більше посилює дисфункцію малого дуоденального сосочка, тим самим посилюючи стаз в додатковій протоці підшлункової залози.

Схематично, фактори, що сприяють виникненню парадуоденального панкреатиту, зображено на рисунку 2.

Характерне розташування вогнищ запалення навколо малого сосочка дванадцятипалої кишки вказує на анатомічну або функціональну схильність даної ділянки до ураження [10, 11]. У значної частини пацієнтів із парадуоденальним панкреатитом спостерігається різко звужена або звивиста Санторінієва протока, або ж наявна pancreasdivisum

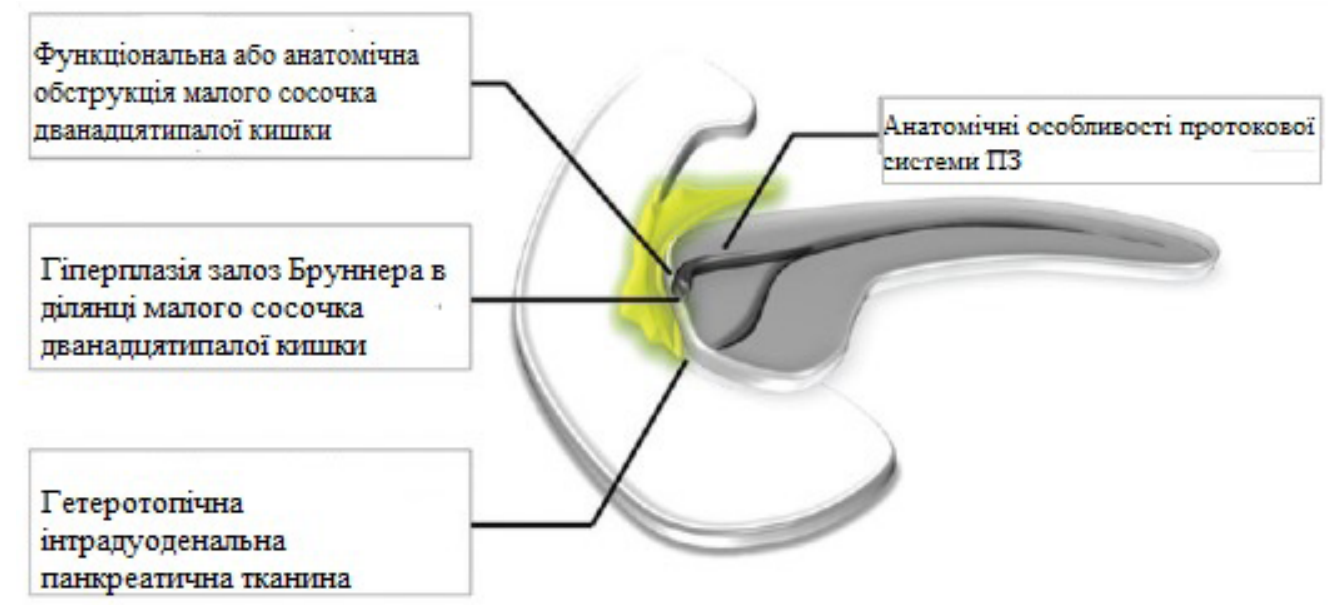

Рис. 2. Фактори, що сприяють виникненню парадуоденального панкреатиту. 
$[18,19]$. Підвищення в'язкості панкреатичного соку разом з анатомічними особливостями протокової системи підшлункової залози, зокрема додаткової протоки, призводять до зростання гідростатичного тиску та посиленого опору відтоку панкреатичного соку, пошкодження, а згодом до фіброзу і кальцифікації Санторінієвої протоки, маленького сосочка та стінки дванадцятипалої кишки, прилеглої паренхіми підшлункової залози $[11,12]$. Кістозні зміни дванадцятипалої кишки та гіперплазія залоз Бруннера в ділянці її маленького сосочка є відмінною рисою парадуоденального панкреатиту, що пов'язано із обструкцією додаткової протоки підшлункової залози (рис. 3).

Вважається, що патогенез даного явища пов'язаний із підвищенням рівня гастрину чи холецистокінін - панкреазиму $[7,17]$. Це, в свою чергу, призводить до стазу панкреатичного соку в ділянці дорсального зачатка підшлункової залози та розриву протоки. При цьому екстравазація мукопротеїну в навколишні тканини супроводжується макрофагальною реакцією та запальними змінами в ділянці “борозни” [17]. В певних випадках порушення ембріогенезу та неповна інволюція дорсального зачатку підшлункової залози зумовлює наявність панкреатичної паренхіми в стінці дванадцятипалої кишки, що є передумовою для виникнення groove панкреатиту [11, 12, 17].

Клінічний перебіг захворювання супроводжується появою болю в животі, диспепсични- ми розладами, характерними для перебігу хронічного панкреатиту. Постпрандіальне блювання та втрата маси тіла, що, як правило, виникає в пізні терміни захворювання, свідчить про дуоденальний стеноз [11, 12]. У більшості пацієнтів виявляють тубулярний стеноз холедоха, проте клініка обструктивної жовтяниці настає рідко і більш характерна для пухлин періампулярної зони. Тривалість клінічних симптомів від початку захворювання і до встановлення діагнозу триває від декількох тижнів до року, в середньому 3-6 міс. [11, $12,17,18]$.

Традиційно виділяють дві форми groove панкреатиту. Чиста форма вражає лише панкреатодуоденальну борозну (тобто анатомічний простір між головкою підшлункової залози та дванадцятипалою кишкою), тоді як сегментарна форма хоча і зосереджена в борозні, проте поширюється медіальніше в головку підшлункової залози та часто вражає головну панкреатичну протоку. Демаркація між даними двома формами парадуоденального панкреатиту не завжди цілковито чітка. В деяких випадках чиста форма groove панкреатиту спричиняє прогресивне звуження панкреатичної протоки i, як наслідок, призводить до дифузного хронічного запалення паренхіми підшлункової залози [19].

При патологогістологічному дослідженні стінка дванадцятипалої кишки поблизу малого сосочка значно потовщена, рубцево змінена, дефор-

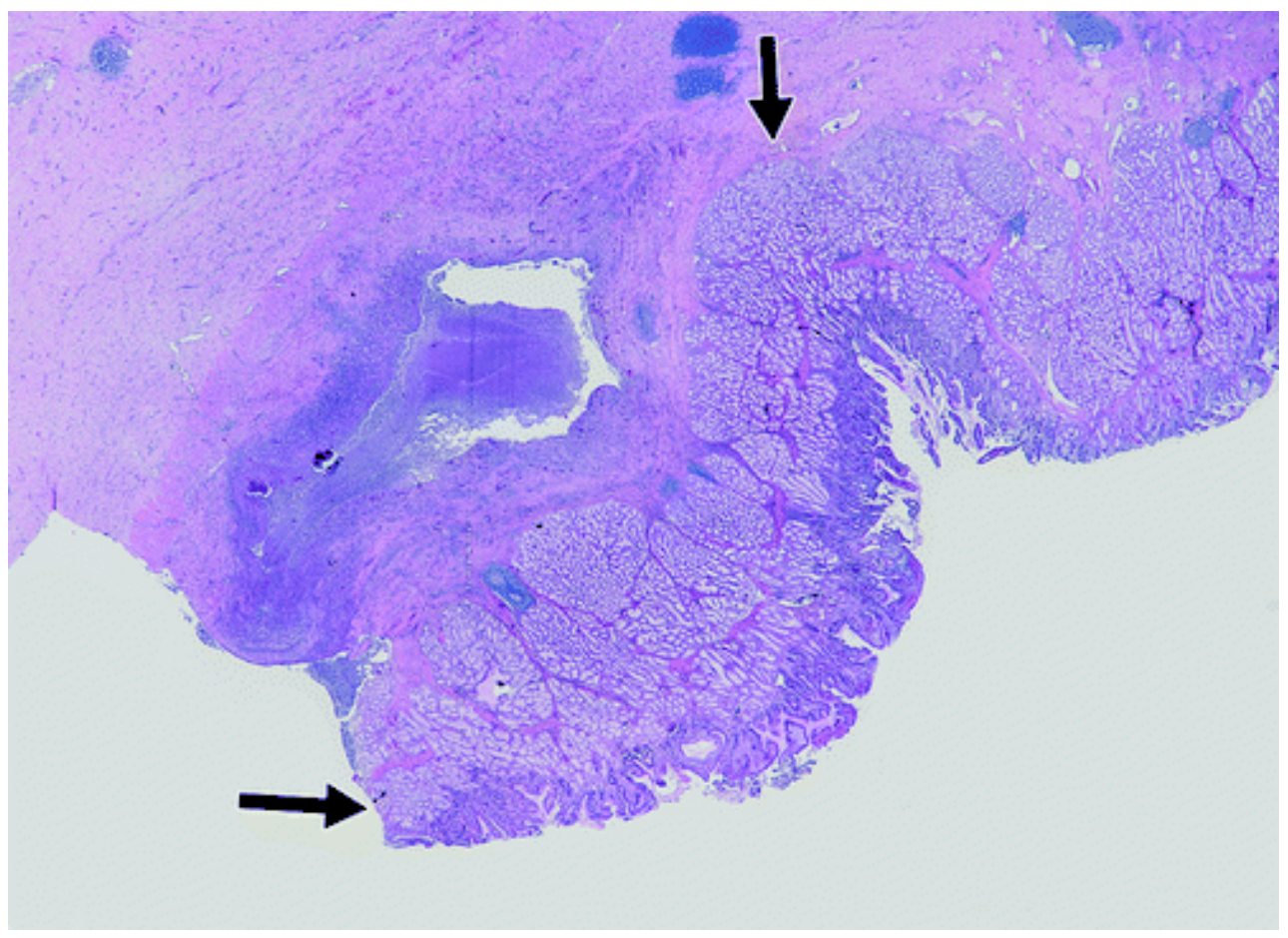

Рис. 3. Чорними стрілками позначено гіперплазію залоз Бруннера та кістозні зміни стінки дванадцятипалої кишки в ділянці панкреатодуоденальної борозни. 
муючи просвіт ДПК. Великий дуоденальний сосок при цьому незмінений $[9,11,12,20]$. На секції епіцентр патологічного процесу типово розташований в панкреатодуоденальній борозні, щільно еластичної чи желатиноподібної консистенції, може містити кісти. Розміри кіст можуть варіювати від 0,2 до 2 см і, як правило, виявляються в підслизовому та м’язовому шарах, містять рідинний компонент, білу грануляційну тканину чи навіть конкременти [7, 12, 19]. Окремі автори відмітили ці зміни у 49 \% пацієнтів в своїх дослідженнях
[7]. При мікроскопічному дослідженні, порожнини кіст вистелені циліндричним епітелієм або замінені грануляційною тканиною. Залози Бруннера гіперплазовані, спостерігається потовщення та фіброзні зміни підслизового і м'язового шарів ДПК $[11,12,19]$. Паренхіма головки підшлункової залози фіброзно, рубцево змінена, втягнена в запальний процес в ділянці панкреатодуоденальної борозни $[9,13,19]$. Втягнення в процес основної маси паренхіми головки підшлункової залози сричиняє дилатацію Вірсунгової протоки (рис. 4).
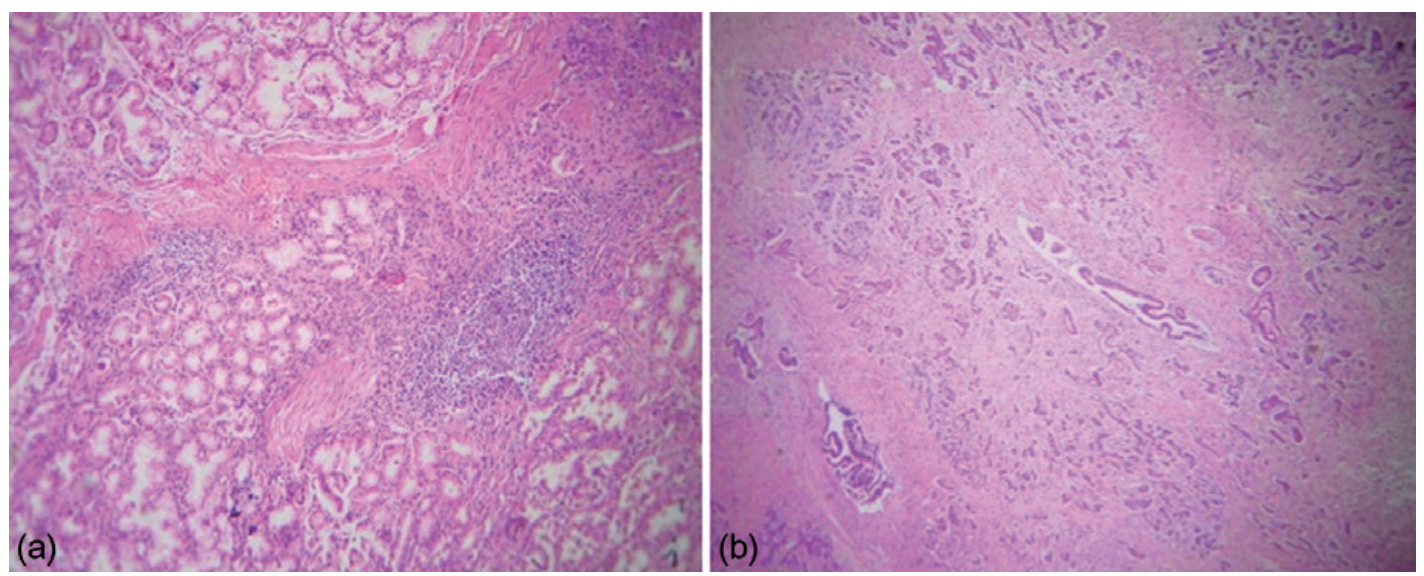

Рис. 4. Мікроскопічне дослідження показує (а) ділянку панкреатодуоденальної борозни з гіперплазією залоз Бруннера та хронічним запаленням (збільшення х 100) та (b) виражений фіброз та помірне розширення панкреатичної протоки (збільшення х 40).

Характерно, що чиста форма groove панкреатиту, як правило, виникає в ділянці додаткової панкреатичної протоки, що не вкрита паренхімою підшлункової залози, неподалік від місця ії̈ впадання в дванадцятипалу кишку. При мікроскопічному дослідженні виявлено, що ця ділянка оточена проліферуючими міофібробластами, які можуть спричиняти втягнення в патологічний процес дванадцятипалу кишку, паренхіму підшлункової залози та загальну жовчну протоку. Стромальна тканина, що оточує ці кісти, потенційно може вказати на рівень реактивної клітинної атипії [12]. В умовах патологічного вогнища дана атипія може помилково бути сприйнята за злоякісний новоутвір.

\section{СПИСОК ЛІТЕРАТУРИ}

1. Хирургия поджелудочной железы / А. А. Шалимов, С. А. Шалимов, М. Е. Ничитайло, А. П. Радзиховский // Симферополь : Таврида, 1997. - 506 с.

2. Ничитайло М. Е. Кисты и кистозные опухоли поджелудочной железы / М. Е. Ничитайло, Ю. В. Снопок, И. И. Булик. - Киев : ЧАО «Полиграфкнига», 2012. - 544 с.

3. Хронический панкреатит. Современные концепции патогенеза, диагностики и лечения / А. А. Шалимов, В. В. Грубник, Дж. Горовиц [и др.] // К. : Здоровья, 2000. - 255 с.

4. Pancreatico-duodenectomy for complicated groove pancreatitis / S. H. Rahman, C. S. Verbeke, D. Gomez [et al.]. //
Гетеротопію підшлункової залози найчастіше виявляють на автопсіях (1,05-12,30 \%), патологогістологічному дослідженні видаленого матеріалу після операційних втручань або при ендоскопічному дослідженні верхніх відділів шлунковокишкового тракту.

У зв'язку із тяжкістю диференціації groove панкреатиту та пухлинами періампулярної зони, його діагностика повинна бути комплексна та включати специфічні клініко-анамнестичні, лабораторні та інструментальні методи дослідження, проте остаточний діагноз можливий лише при гістологічному підтвердженні після видалення патологічного вогнища.

HPB (Oxford). - Vol. 9 (3). - P. 229-234.

5. Pancreatic hamartoma / C. D. McFaul, L. J. Vitone, F. Campbell [et al.] // Pancreatology. - 2004.

6. Myoepithelial hamartoma of the duodenal wall / A. Ryan, J. R. Lafnitzegger, D. H. Lin [et al.] // Virchows Arch. - 1998. Vol. 432. - P. 91-94.

7. Becker V. Groove pancreatitis / V. Becker, U. Mischke // Int. J. Pancreatol. - 1991. - Vol. 10. - P. 173-182.

8. Potet F. Cystic dystrophy on aberrant pancreas of the duodenalwall / F. Potet, N. Duclert // Arch. Fr. Mal. App. Dig. - 1970. - Vol. 59 (4). - P. 223-238. 
9. A special form of segmental pancreatitis: "groove pancreatitis” / M. Stolte, W. Weiss, H. Volkholz, W. Rosch // Hepatogastroenterology. - 1982. - Vol. 29 (5). - P. 198-208.

10. Kim J. D. Characteristic clinical and pathologic features for preoperative diagnosed groove pancreatitis / J. D. Kim, Y. S. Han, D. L. Choi // J. Korean Surg. Soc. - 2011. - Vol. 80. - P. 342-347. 11. Groove pancreatitis: a diagnostic challenge / C. Triantopoulou, C. Dervenis, N. Giannakou [et. al.] // Eur. Radiol. - 2009. Vol. 19. - P. 1736-1743.

12. Groove pancreatitis / K. Tezuka, T. Y. Makino, I. Hirai, W. Kimura // Dig. Surg. - 2010. - Vol. 27. - P. 149-152.

13. Groove pancreatitis: a mini-series report and review of the literature / A. Manzelli, A. Petrou, A. Lazzaro [et al.] // JOP. 2011. - Vol. 12. - P. 230-233.

14. Pancreatico-duodenectomy for complicated groove pancreatitis / S. H. Rahman, C. S. Verbeke, D. Gomez [et al.] // HPB (Oxford). - Vol. 9. - P. 229-234.

15. Cystic form of paraduodenal pancreatitis (cystic dystrophy in

\section{REFERENCES}

1. Shalimov, A.A., Shalimov, S.A., Nychytaylo, M.Ye., \& Radzikhovsky, A.P. (1997). Khirurgiya podzheludochnoi zhelezy [Surgery of the pancreas]. Simferopol: Tavrida [in Russian]. 2. Nychytaylo, M.Ye., Snopok, Yu.V., \& Bulyk, I.I. (2012). Kisty i kistoznyye opukholy podzheludochnoy zhelezy [Cysts and cystic pancreatic tumors]. Kyiv: Pjsc "Poligrafkniga" [in Russian].

3. Shalimov, A.A., Grubnik, V.V., \& Gorovyts, Dzh. (2000). Khronicheskiy pankreatyt. Sovremennyye kontseptsiy patogeneza, diagnostiky i lecheniya [Chronic pancreatitis. Modern concepts of pathogenesis, diagnosis and treatment]. Kyiv: Zdorovia [in Russian].

4. Rahman, S.H., Verbeke, C.S., Gomez, D., McMahon, M.J., \& Menon K.V. (2007). Pancreatico-duodenectomy for complicated groove pancreatitis HPB (Oxford), 9 (3), 229-234.

5. McFaul, C.D., Vitone, L.J., Campbell, F., Azadeh, B., Hughes, M.L., \& Garvey C.J. (2004). Pancreatic hamartoma. Pancreatology.

6. Ryan, A., Lafnitzegger, J.R., Lin, D.H., Jakate, S., \& Staran, E.D. (1998). Myoepithelial hamartoma of the duodenal wall. Virchows Arch, 432, 191-194.

7. Becker, V., \& Mischke, U. (1991). Groove pancreatitis. Int. J. Pancreatol., 10, 173-182.

8. Potet, F., \& Duclert, N. (1970). Cystic dystrophy on aberrant pancreas of the duodenalwall. Arch. Fr. Mal. App. Dig., 59 (4), 223-238.

9. Stolte, M., Weiss, W., Volkholz, H., \& Rosch W.A. (1982). Special form of segmental pancreatitis: "groove pancreatitis". Hepatogastroenterology, 29 (5), 198-208.

10. Kim, J.D., Han, Y.S., \& Choi, D.L. (2011). Characteristic clinical and pathologic features for preoperative diagnosed groove heterotopic pancreas (CDHP)): A potential link with minor papilla abnormalities? A study in a large series / M. Wagner, M. P. Vullierme, V. Rebours [et al.] // Eur. Radiol. - 2015. - Vol. 1. - P. 1-7. 16. Warshaw A. L. The cause and treatment of pancreatitis associated with pancreas divisum / A. L. Warshaw, J. M. Richter, R. H. Schapiro // Ann. Surg. - 1983. - Vol. 198. - P. 443-452.

17. "Paraduodenal" pancreatitis: results of surgery on 58 consecutives patients from a single institution / L. Casetti, C. Bassi, R. Salvia [et al.] // World J. Surg. - 2009. - Vol. 33. - P. 2664-2669.

18. Groove pancreatitis: a case report and review of literature / V. Balakrishnan, S. Chatni, L. Radhakrishnan [et al.] // JOP. 2007. - Vol. 8. - P. 592-597.

19. Adsay N. V. Paraduodenal pancreatitis: a clinicopathologically distinct entity unifying "cystic dystrophy of heterotopic pancreas", "para-duodenal wall cyst", and "groove pancreatitis" / N. V. Adsay, G. Zamboni // Semin. Diagn. Pathol. - 2004. Vol. 21: 247-254.

pancreatitis. J. Korean Surg. Soc. 80, 342-347.

11. Triantopoulou, C., Dervenis, C., \& Giannakou N. (2009). Groove pancreatitis: a diagnosticchallenge. Eur. Radiol., 19, 1736-1743.

12. Tezuka, K., Makino, T.Y., Hirai, I., \& Kimura, W. (2010). Groove pancreatitis. Dig. Surg., 27, 149-152.

13. Manzelli, A., Petrou, A., \& Lazzaro, A. (2011). Groove pancreatitis: a mini-seriesreportandreviewoftheliterature. JOP., 12, 230-233.

14. Rahman, S.H., Verbeke, C.S., Gomez, D., McMahon, M.J., \& Menon, K.V. (2007). Pancreatico-duodenectomy for complicated groove pancreatitis. HPB (Oxford), 9, 229-234.

15. Wagner, M., Vullierme, M.P., Rebours, V., Ronot, M., Ruszniewski, P., \& Vilgrain, V. (2015). Cystic form of paraduodenal pancreatitis (cystic dystrophy in heterotopic pancreas (CDHP)): A potential link with minor papilla abnormalities? A study in a large series. Eur. Radiol, 1, 1-7.

16. Warshaw A.L., Richter J.M., \& Schapiro R.H. (1983). The cause and treatment to pancreatitis associated with pancreas divisum. Ann. Surg., 198, 443-452.

17. Casetti, L., Bassi, C., Salvia, R., Butturini, G., \& Graziani, R. (2009). "Paraduodenal" pancreatitis: results of surgery on 58 consecutives patients from a single institution. World J. Surg., 33, 2664-2669.

18. Balakrishnan V., Chatni S., Radhakrishnan L., Narayanan V.A., Nair P. (2007). Groove pancreatitis: a case report and review of literature. JOP, 8, 592-597.

19. Adsay, N.V., \& Zamboni, G. (2004). Paraduodenal pancreatitis: a clinicopathologically distinct entity unifying "cystic dystrophy of heterotopic pancreas", "para-duodenal wall cyst", and "groove pancreatitis”. Semin. Diagn. Pathol., 21, 247-254. 
M. YU. NYCHYTAILO, I. I. BULYK, L. R. NAZARKO, A. A. HORBUNOV, A. V. KOLESNYK

O. Shalimov National Institute of Surgery and Transplantology

\title{
PARADUODENAL (GROOVE) PANCREATITIS. TERMINOLOGY, ETIOPATHOGENESIS, PATHOMORPHOLOGY
}

\begin{abstract}
Groove pancreatitis is a rare type of focal chronic pancreatitis, affecting "the groove "- - the anatomical space between the dorsocranial part of the head pancreas, the duodenum, and the common bile duct. The following synonyms of groove pancreatitis are recognized in literature: cystic dystrophy of heterotopic pancreas, pancreatic hamartoma of duodenum, myoadenomatosis. The pathogenesis of paraduodenal pancreatitis remains controversial. It has been suggested to occur because of increasing viscosity of the pancreatic juices in the ductal system, which cause disturbance of outflow pancreatic juices, damage of pancreatic tissue and as result inflammation of surrounding structures. Groove pancreatitis can generate diagnostic challenges for clinicists and pathologists by imitating pancreatic carcinoma. A definitive diagnosis can be extraordinarily difficult, and an inability to distinguish groove pancreatitis from a primary duodenal, ampullary, or pancreatic malignancy often leads to surgery. This review will describe the etiology, pathophysiology and morphological changes of groove pancreatitis.
\end{abstract}

Key words: paraduodenal pancreatitis; chronic inflammation; pancreas.

М. Ю. НИЧИТАЙЛО, И. И. БУЛИК, Л. Р. НАЗАРКО, А. А. ГОРБУНОВ, А. В. КОЛЕСНИК

ГУ “Национальный институт хирургии и трансплантологии имени А. А. Шалимова" НАМН Украины

\section{ПАРАДУОДЕНАЛЬНЫЙ (GROОVЕ) ПАНКРЕАТИТ. ТЕРМИНОЛОГИЯ, ЭТИОПАТОГЕНЕЗ, ПАТОМОРФОЛОГИЯ}

\begin{abstract}
Парадуоденальный, или grooveпанкреатит,являетсяредким типом фокального хронического воспаленияподжелудочнойжелезы, преимущественно поражая “борозду” - анатомическое пространство между дорсокраниальной частью головки поджелудочной железы, двенадцатиперстной кишкой и общим желчным протоком. В литературе встречается под следующими синонимами: дуоденальная дистрофия гетеротопической поджелудочной железы, панкреатическая гамартома двенадцатиперстной кишки, миоаденоматоз. Спорным остается вопрос патогенеза парадуоденального панкреатита. Основными этиопатогенетическими факторами заболевания являются анатомические особенности протоковой системы поджелудочной железы и повышение плотности панкреатического сока, которые приводят к хроническому персистирующему воспалению в области “борозды” с последующим вовлечением в патологический процесс головки поджелудочной железы, двенадцатиперстной кишки и терминального отдела холедоха. Тяжесть дифференциации groove панкреатита с опухолями периампулярной зоны создает определенные диагностические трудности для клиницистов и патоморфологов, что требует проведения оперативного лечения для верификации окончательного диагноза. Данное сообщение описывает основные этиологические, патофизиологические и морфологические изменения, возникающие при парадуоденальном панкреатите.
\end{abstract}

Ключевые слова: парадуоденальный панкреатит; хроническое воспаление; поджелудочная железа. 